\title{
Recent Advances in the Ultraviolet Protection Finishing of Textiles
}

\author{
Najsodobnejši izsledki na področju plemenitenja tekstilij za \\ zaščito pred ultravijoličnim sevanjem
}

\author{
Scientific Review/Pregledni znanstveni članek \\ Received/ Prispelo 09-2018. Accepted/ Sprejeto 09-2018
}

\begin{abstract}
This paper reviews the recent research in the field of application of ultraviolet (UV) protection finishes in textile functionalisation. The aim and the UV protecting mechanisms of UV protection finishes on textile substrates are described. The standard methods for determination of UV protective properties are presented. Contemporary research directions in the application of environmentally friendly organic UV absorbers and inorganic UV blockers are highlighted and discussed. The bioactive substances as novel organic UV absorbers are exposed. Novel multifunctional properties of textiles including the inorganic UV blockers are described. The ecological issues of the use of UV protection finishes are presented.

Keywords: textiles, UV protection, inorganic nanoparticles, plant extracts, multifunctional properties, ecological issues
\end{abstract}

\section{Izvleček}

Prispevek vključuje pregled najsodobnejših raziskav na področju uporabe apreturnih sredstev za zaščito pred ultravijoličnim (UV) sevanjem (UV-zaščitna sredstva) pri funkcionalizaciji tekstilij. Opisani so namen in mehanizmi delovanja UV-zaščitnih sredstev na tekstilnih substratih. Predstavljene so standardne metode za določitev UV-zaščitnih lastnosti. Izpostavljene so najsodobnejše raziskovalne usmeritve na področjih uporabe organskih UV-absorberjev in anorganskih UV-blokirnih sredstev. Izpostavljene so bioaktivne substance kot novi okolju prijazni organski UV-absorberji. Opisane so večfunkcionalne lastnosti tekstilij z vključenimi anorganskimi UV-blokirnimi sredstvi. Predstavljeni so ekološki vidiki uporabe UV-zaščitnih sredstev.

Ključne besede: tekstilije, UV-zaščita, ekstrakti rastlin, anorganski nanodelci, večfunkcionalne lastnosti, ekološki vidik

\section{Introduction}

Ultraviolet (UV) protection finishes, which are sometimes referred to as UV shielding agents, represent one of the most important groups of chemical finishing agents applied to textile materials, with the goal of protecting people and textile materials from the harmful effects of UV radiation. The energy of UV radiation, which is significantly higher than that of visible light, has the potential to initiate different chemical reactions that may be hazardous

Corresponding author/Korespondenčna avtorica:

Prof dr. Barbara Simončič

E-mail: barbara.simoncic@ntf.uni-lj.si to human health and can deteriorate textile fibres. Although moderate sun exposure has beneficial health effects, overexposure to UV radiation may result in serious harmful health effects since both UVA (320-400 $\mathrm{nm})$ and UVB (280-320 $\mathrm{nm})$ rays induce different cellular responses that manifest as pigmentation, sunburn, skin ageing, skin cancer and DNA damage [1-3]. The disadvantages of longterm exposure of textiles to UV weathering are associated with the cleavage of different chemical bonds by the absorbed UV radiation, which leads to

Tekstilec, 2018, 61(3), 201-220

DOI: 10.14502/Tekstilec2018.61.201-220 
photochemical degradation of textile fibres, colour fading, increased crystallinity and other chemical and physical changes [4]. Therefore, UV protection finishes are widely used in the production of functional textiles for sportswear, high-altitude clothing, covering materials, wearable sensors and other technical textiles with high added value.

UV protection finishes can be divided into two main groups based on their chemical structure: organic and inorganic agents. The main task of UV protection finishes is to absorb harmful UV radiation and convert this electron excitation energy into harmless heat energy. This mechanism of UV protection applies to organic agents, which are able to absorb and quickly transform UV energy into kinetic and heat energy without photodegradation [4, 5]. These agents are usually called UV absorbers. Since they are widely used for the prevention of photo-oxidation and the photoaging process in textile fibres, these agents are occasionally referred to as photostabilising additives [6].

Novel inorganic UV protection finishes named UV blockers are available on the market, and they mostly include metal oxides (MOs) in the form of nanoparticles (NPs); however, the UV blocking mechanism is not fully clarified and still under debate [7]. Despite the general assumption that the excellent UV blocking performance of MOs NPs is related to the absorption of UV radiation via the semiconductive properties of these NPs, MOs NPs also refract and/or scatter most UV rays via their high refractive index $[8,9]$. Moreover, the protective mechanism of inorganic UV blockers is directly dependent of the chemical structure of the particles as well as their size, shape, crystallinity degree and crystal form [10]. However, because UV blockers are main- ly used to protect the skin from UV radiation, their main task when included in clothing is to prevent direct and diffuse UV transmittance of UV rays via the textile material (Figure 1).

In addition to UV protective finishes applied for sun protective clothing, the UV protective properties of textiles can be significantly improved by designing special textile structures with the appropriate fibre type, yarn structure, fabric construction with low porosity and high cover factor and by using dyes that absorb radiation in near the UV region [11]. The protective properties of clothing can be quantified using in vivo or in vitro methods. In the case of in vivo methods, the sun protection factor (SPF) is determined as the ratio between the minimum erythema dose (MED) on protected skin and unprotected skin [12]:

$$
S P F=\frac{M E D(\text { proected skin })}{M E D(\text { unprotected skin })}
$$

In in vitro method, which is usually used for determination of the effectiveness of sun protective clothing, the ultraviolet protection factor (UPF) is a measure of the textile protection performance for both UVA and UVB radiation. UPF is calculated from the ratio of the UV radiation transmitted through air and the UV radiation transmitted through the fabric according to the European standard EN 13758 Textiles - Solar UV protective properties [12] as follows:

$$
U P F=\frac{\sum_{\lambda=290}^{400} E_{\lambda} \times S_{\lambda} \times \Delta_{\lambda}}{\sum_{\lambda=290}^{400} E_{\lambda} \times S_{\lambda} \times T_{\lambda} \times \Delta \lambda}
$$

where $E_{\lambda}$ is the relative erythemal spectral effectiveness, $S_{\lambda}$ is the solar spectral irradiance, $T_{\lambda}$ is

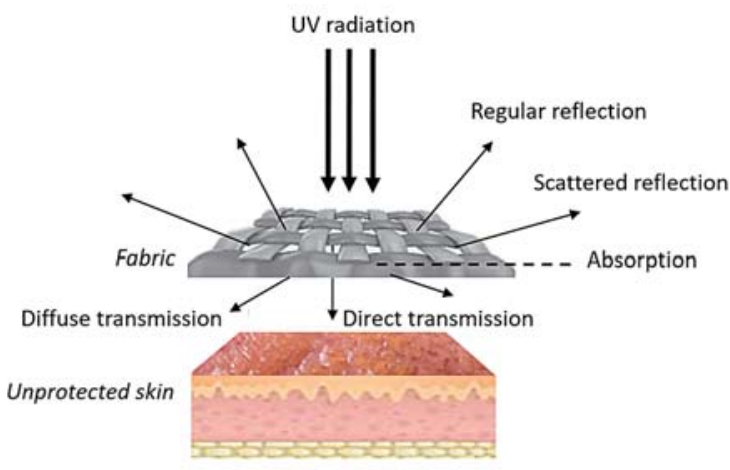

a)

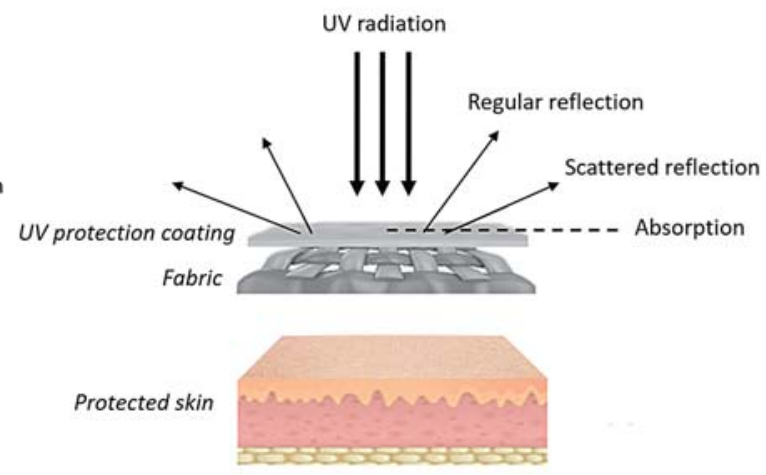

b)

Figure 1: Schematic presentation of UV radiation in the case of the unprotected (a) and protected (b) fabrics 


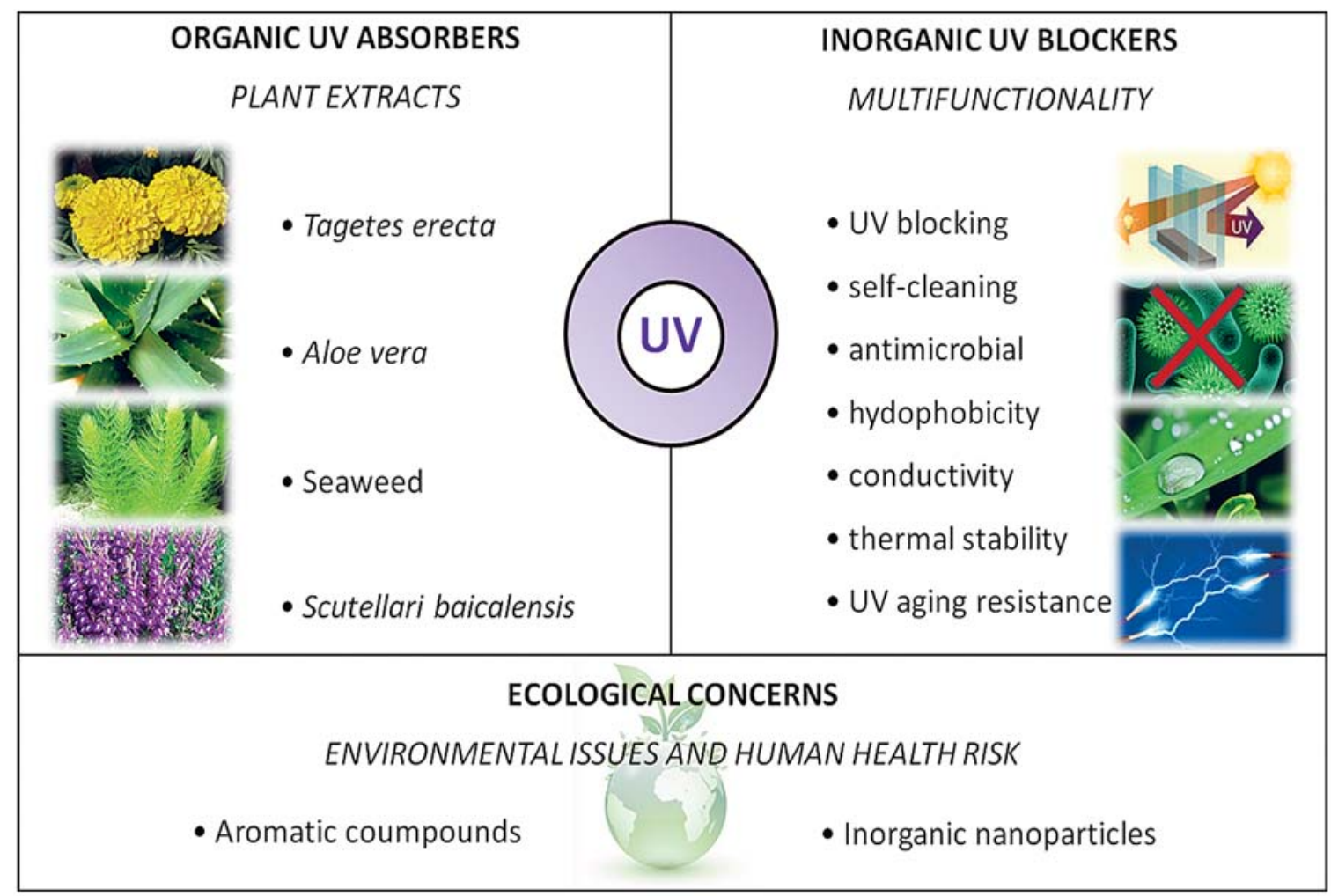

Figure 2: Schematic presentation of the most contemporary research directions related to the UV protection finishing of textiles

average spectral transmittance of the textile material and $\Delta \lambda$ is measured wavelength interval. The latter differs regarding the standard methods and is in the region od $280-400 \mathrm{~nm}$ in the case of the American Association of Textile Chemists and Colorists (AATCC) standard test method AATCC 183 , and in the region of $280-380 \mathrm{~nm}$ in the case of the Australia/New Zeland Standard method AS/ NZS 4399.

Depending on the UPF value, the AS/NZ 4399 standard classifies protective clothing into three categories, i.e. excellent with the UPF values are 40-50, 50 and higher, very good with the UPF values in the range of 25-39 and good with the UPF values in the range of 15-24. According to the EN 13758 standard, the UPF value for the protective clothing should be larger than 40 . The UVA average transmission should be smaller than $5 \%$.

This paper reviews the most contemporary research directions in the application of organic UV absorbers and inorganic UV blockers as well as the ecological aspect of the use of UV protection finishes (Figure 2).

\section{Application of UV protection finishes}

\subsection{Organic UV absorbers}

Organic UV absorbers are uncoloured organic aromatic molecules with conjugated double bonds that absorb UV energy with wavelengths of 290-360 $\mathrm{nm}$, which causes the molecules to reach an excited state; UV energy is then transformed to vibration energy in the UV absorber molecule and heat energy is released to the surrounding environment when the molecules return to the ground state $[4,5,11]$. According to this protection mechanism, UV absorbers protect textile fibres from chain fission and cross-linking reactions caused by the photooxidation of polymers, which reduces the weathering rate of textile fibres. To retain a long-lasting activity, UV absorbers should be stable on exposure to UV radiation $[6,13]$, and they should return to their original form after the reaction. If the molecules of UV absorbers are permanently transformed into their non-absorbing isomers, their UV absorbing properties are destroyed. 
Technologically, the most important organic UV absorbers include derivatives of hydroxyphenylbenzotriazoles, hydroxyphenylbenzophenones and hydroxyphenyltriazines (Figure 3) [4-6, 14-16], which can be used for natural and synthetic fibres and applied alone or in combination with synergistically active antioxidants [6]. Whereas organic UV absorbers are mostly used as finishing agents, they can be also incorporated as fillers in the spinning process of chemical fibres. From a technological point of view, poor washing durability is one of the most important disadvantages of organic UV absorbers. Inspired by<smiles>[Y]c1ccc(-n2nc3ccccc3n2)c(O)c1</smiles>

a)<smiles>O=C(c1ccc(O)cc1O)c1ccc(Cl)cc1O</smiles>

b)<smiles>[Y]c1ccc(-c2ncnc(C)n2)c(O)c1</smiles>

c)

Figure 3: Chemical structures of derivatives of hydroxyphenylbenzotriazoles (a), hydroxyphenylbenzophenones (b) and hydroxyphenyltriazines (c) [5]<smiles>COC(=O)Oc1ccc(Nc2nc(Cl)nc(Nc3ccc(-n4nc5ccccc5n4)c(O)c3)n2)cc1</smiles><smiles>[R]c1nc(Nc2ccc(Nc3nc([R])nc(Cl)n3)c([N+]([O])([O-])[O-])c2)nc(Nc2ccc(Nc3nc([R])nc(Cl)n3)c(S(=O)(=O)O)c2)n1</smiles>

b)<smiles>O=C(c1ccccc1)c1ccc(Oc2nc(Cl)nc(Cl)n2)cc1O</smiles>

c)<smiles>N#CNC(=N)N1C(O)C1O</smiles>

Figure 4: Chemical structures of fibre-reactive UV absorbers based on benzotriazole derivative (a), symmetrical triazine derivative (b), benzophenone derivative (c) and $N$-dihydroxy ethylene cyanoguanidine (d) [14, 17-19] 
the structure of reactive dyes, chlorotriazine, vinylsulfone and $\mathrm{N}$-dihydroxy ethylene reactive groups have been introduced to the UV absorber molecules to provide their high fixation efficiency [14, 17-19]. Among reactive UV absorbers, condensation products of aminophenylbenzotriazoles and cyanuric chloride, derivatives of symmetrical triazine 4-(4,6dichloro-1,3,5-triazin-2-yloxy)-2-hydroxyphenyl) (phenyl) methanone and $\mathrm{N}$-dihydroxy ethylene cyanoguanidine were thoroughly investigated (Figure 4) [14, 17-19]. These compounds can be covalently bonded to the hydroxyl groups of cellulose fibres, which significantly increases their durability.

The growing use of synthetic organic UV absorbers in recent decades have caused environmental concerns since different toxic degradation products of UV absorbers can bioaccumulate. Therefore, in recent years, considerable effort has been invested in the investigation of UV-absorbing bioactive substances and their introduction into new environmentally friendly production processes of textiles with UV protection properties. Namely, bioactive substances represent biodegradable and never-ending resources of natural finishes.

Extracts of various plants were studied in this research as UV-absorbing bioactive substances. These include flavonoids, such as flavone, flavonol, luteolin and baicalin, mycrosphorine-like amino acids, tannin, lutein and aloin (Figure 5) [20-27]. Most plant extracts also exhibit antimicrobial, anticancer and antioxidant properties antiviral activity, which enable them to be used in the development of medical, health and hygiene-related textile materials.

Aloe vera active substances including flavonoids, aloins, tannins, terpenoids, saponins, anthraquinone derivatives, aloe-emodin-9-anthrone and anthrone-C-glycosidesin have been the subject of many research over the last few years. Aloa vera has several positive characteristics, such as non-cytotoxicity,<smiles>O=c1cc(-c2ccccc2)oc2ccccc12</smiles>

a)

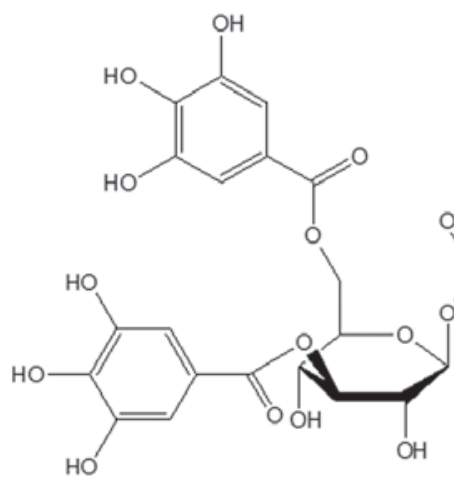

d)<smiles>O=c1c(O)c(-c2ccc(O)c(O)c2)oc2cc(O)cc(O)c12</smiles>

b)<smiles>O=C1CC(c2ccccc2)Oc2cc(OC3O[C@H](C(=O)O)[C@@H]4O[C@H]3[C@@H](O)[C@H]4O)c(O)c(O)c21</smiles><smiles>O=C1C2=C(O)[C@@H](O)[C@@H](O2)[C@H]2OC(c3cccc(O)c31)c1cc(CO)cc(O)c1C2=O</smiles>

e)<smiles>CC1=CC(O)CC(C)(C)C1/C=C/C(C)=C/C=C/C(C)=C/C=C(C)/C=C/C=C(C)/C=C/C1=C(C)CC(O)CC1(C)C</smiles>

f)

Figure 5: Chemical structures of natural organic UV absorbers: flavone (a), luteolin (b) baicalin (c), tannin (d), aloin (e) and lutein $(f)$ 
antimicrobial, UV absorbing, wound healing and other therapeutic properties [20]. For textile application, Aloe vera nanopowder was dissolved in water in the presence of chitosan as the stabilising agent using the sonification procedure to prepare Aloe vera/chitosan nanocomposite [21]. Afterwards, a homogeneous solution was coated on cotton fabric using the pad-dry-cure method. The treated cotton fabric showed good UV protection properties with the UPF value higher than 50 which was attributed to the presence of Aloe vera particles with the absorption maxima in UVB region. A significant amount of Aloe vera/chitosan nanocomposite was found to remain even after ten washings which proved the washing durability of the coating. In addition to UV protection, the coated fabric showed excellent water repellent properties as well as antimicrobial activity. This highlighted the potential application of Aloe vera/chitosan nanocomposite for multifunctional protective clothing in defence and biomedical fields.

Carotenoid compounds lutein and lutein esters which represent the main chemical components of marigold (Tagetes erecta) flowers extract have already been established textile dyeing and protective finishing $[23,24]$. To create UV protection and antioxidant properties with simultaneous coloration on a wool fabric, the extracted solution was applied to un-mordanted and mordanted wool samples by exhaustion procedure [23]. The results showed that the marigold extract did not only dye the wool fibres in yellow colour but also appreciably improved the UV absorption properties. The presence of iron mordant increased the UV protection due to its UV screening abilities. The abstraction of peroxy free radicals by lutein resulted in excellent antioxidant activity that was also enhanced in the presence of mordants.

Baicalin which is a plant extract from Scutellaria baicalensis and belongs to the family of flavonoids was applied to silk fabric by exhaustion procedure [25]. It was found that the presence of baicalin provided very good UV protection ability for silk fabric due to its strong absorption capability in the UVB region. Unexpectedly, the UV protection effect of baicalin was even better than that of the benzotriazole-based UV absorber which was used for comparison due to baicalin is also a good free radical scavenger, the treated silk fabric exhibited a very good antioxidant activity. Another advantage of baicalin is its very pale colour, which has a small impact on the colour of textile material.

Due to their various functionalities, such as antioxidant, antimicrobial, UV protective, anti-inflammatory, anticoagulant, anti-tumour and biodegradable properties, bioactive substances extracted from marine macroalgae (seaweeds), which are highly promising plant-like organisms of brown, red and green colours, already have a widespread use in the production of medical, healthcare, hygiene and protective textiles [27]. As a source of natural UV protection finishes with the antioxidant property, flavonoids, tannins and mycrosphorine-like amino acids are of great importance. They were applied to the cellulose fibres using the exhaustion or pad-dry procedures. Since seaweed represents a natural-based cellulosic fibre, brown algae were dissolved in a solvent containing water and the filament yarns were manufactured through a solvent-spinning process. The woven and knitted fabrics produced with seaweed fibres exhibited unique durable multifunctional protective properties of macroalgae.

\subsection{Inorganic UV blockers}

Various semiconducting materials exhibit UV blocking properties, including $\mathrm{TiO}_{2}, \mathrm{ZnO}$, cerium dioxide $\left(\mathrm{CeO}_{2}\right)$, zirconium dioxide $\left(\mathrm{ZrO}_{2}\right)$, magnesium oxide $(\mathrm{MgO})$, aluminium trioxide $\left(\mathrm{Al}_{2} \mathrm{O}_{3}\right)$, silicon dioxide $\left(\mathrm{SiO}_{2}\right)$, copper and copper sulphide (CuS), silver $(\mathrm{Ag})$ as well as graphene-based materials [8, 28-38]. Among these inorganic materials, $\mathrm{TiO}_{2}$ and $\mathrm{ZnO}$ alone as well as in combinations are the most widely investigated as UV blockers [39, 40]. Compared with organic UV absorbers, inorganic UV blockers are more biocompatible and much cheaper and have higher thermal and chemical stability, better durability and excellent UV blocking properties over a broad range of UV wavelengths.

$\mathrm{MOs}$ and $\mathrm{CuS}$ are representatives of bang-gap semiconductors and present unique UV protection properties and photocatalytic activity $[41,42]$. These properties are directly influenced by their physicochemical characteristics. In general, NPs are much more effective as UV blockers compared with bulk materials because of their large surface area to volume ratio. Furthermore, NPs with a crystal form are characterised by high refractive indices in the UV and visible wavelength ranges, which is why their UV blocking function is attributed to refraction and/or scattering of UV rays. 
As semiconductors, $\mathrm{MOs}$ and $\mathrm{CuS}$ are characterised by an electron band structure that includes bands with orbitals and gaps in the UV spectral region with no orbitals $[7,43]$. Upon the absorption of UV radiation with energy that matches or exceeds the band gap energy, the electrons from the valence band are excited to the conduction band, thus leaving a positively charged hole in the valence band. This phenomenon of semiconductors confirms that the absorption of UV radiation has a significant role in their UV protection mechanism.

Because the photogenerated free electrons and positive holes generate the formation of reactive oxygen species (ROS), such as ${ }^{\bullet} \mathrm{OH},{ }^{\bullet} \mathrm{OOH}$ and $\mathrm{O}_{2}{ }^{-}$, free radicals which initiate different photocatalytic reactions, which enables semiconductors to be used as photocatalytic self-cleaning and antimicrobial agents as well as photocatalysts for degradation of textile dyes in waste water. However, when using semiconductors as UV protection finishes, their inherent photocatalytic properties can represent an important disadvantage, since photodegradation of dyes and textile fibres leads to colour fading and deterioration of the mechanical properties of textile substrates [8]. Compared with MOs and CuS, graphene is classified as a zero band-gap semiconductor due to its special electronic structure. Because of its high absorption capability in the UV region, graphene represents one of the novel materials for the UV protection of textiles that does not lead to harmful photocatalytic degradation [35].

Inorganic UV blockers can be applied in different textile production stages, among which the electrospinning of nanofibres and finishing of fabrics by the sol-gel technique are of great technological importance $[44,45]$. When applying inorganic UV blockers to textile substrates, researchers have faced several problems associated with the agglomeration of NPs, low adsorption ability of textile fibres for NPs and low durability of the coating. To resolve these problems, new routes of synthesis of NPs have been introduced to improve the dispersity of NPs, such as the in situ growth of NPs on textile fibres in the presence of stabilising agents [31, 46-48]; and the use of hydrothermal, solvothermal, microwave and sputtering deposition methods [32, 45, 49-54]. To enhance the adsorption ability of textile fibres and consequently the washing durability of the coatings, plasma treatments have been used to increase the textile wettability and the surface roughness [54-56], polyester fi- bres have been pre-treated with sodium hydroxide to improve their wettability $[57,58]$ and cellulose fibres have been pre-modified with chloroacetic acid to create new active carboxylic groups [31].

For the production of high added value textile products, the creation of multifunctional properties is of great practical importance. Accordingly, the most contemporary research in the field of UV protection of textile with the use of inorganic UV blockers includes the combination of UV protective properties with antimicrobial, water and oil repellent and easycare properties; water/oil separation capabilities; electrical conductivity; UV aging resistance; thermal stability; and flame retardancy.

Simultaneous UV blocking properties and antimicrobial and self-cleaning activities were generated for protective clothing, sportswear and medical textiles. To this end, $\mathrm{Ag}$ was used in combination with $\mathrm{TiO}_{2}$ and applied to cellulose fibres by different application processes $[50,52$, 59-61]. Commercial $\mathrm{Ag} / \mathrm{TiO}_{2}$ nanocomposites were applied to cotton fabric during the exhaustion dyeing process to simultaneously load $\mathrm{Ag} /$ $\mathrm{TiO}_{2}$ and reactive dye on cotton [59]. The presence of reactive dyes enhanced the adsorption of $\mathrm{Ag} /$ $\mathrm{TiO}_{2}$ nanocomposite, resulting in excellent antimicrobial and UV protective properties that were retained after multiple domestic washings.

Furthermore, the simultaneous colouration and function finishing of cotton fabric were performed using Ag colloids of different colours in combination with $\mathrm{TiO}_{2}$ NPs in an ultrasonic bath [61]. The UV blocking activity, antimicrobial efficiency and selfcleaning property of the cotton fabric treated with the $\mathrm{Ag} / \mathrm{TiO}_{2}$ composite were superior compared with the sample treated with $\mathrm{TiO}_{2} \mathrm{NPs}$ alone. Moreover, the photocatalytic activity of $\mathrm{TiO}_{2}$ had no negative effect on the fabric colour.

Durable antimicrobial and UV protective cotton fabric was also created by the deposition of flowerlike hierarchical $\mathrm{TiO}_{2}$ micro-NPs via hydrothermal deposition followed by the in situ growth of Ag NPs on the surface of $\mathrm{TiO}_{2}$-cotton fabric [50]. This new synthesis route of $\mathrm{Ag} / \mathrm{TiO}_{2}$ composite is appropriate for sustainable biomedical applications.

A prolonged hydrothermal treatment was also performed for the deposition of $\mathrm{Ag}$ doped $\mathrm{TiO}_{2} \mathrm{NPs}$ on cotton fabric [52]. In this novel application method, a small amount of $\mathrm{AgNO}_{3}$ was added to water during the hydrothermal step, which caused the doping 
of $\mathrm{TiO}_{2}$, thereby imparting strong antimicrobial properties to the treated cotton fabric as well as drastically enhancing its UPF value.

Another approach for the preparation of multifunctional finishing includes the sol-gel process, which includes the use of $\mathrm{Al}_{2} \mathrm{O}_{3} / \mathrm{SiO}_{2}$ sol modified with $\mathrm{Ag} / \mathrm{Cu}$ and $\mathrm{TiO}_{2}$ NPs applied to polyester/cotton fabric by pad-dry-cure procedure [62]. A synergistic effect in the interactions between both types of NPs in the coating showed better photocatalytic self-cleaning and protective capabilities against UV radiation as well as bacteria and fungi. Despite the increased roughness of the coating due to the presence of NPs, the coating's resistance to abrasion was not hindered.

$\mathrm{ZnO} / \mathrm{Ag}$ nanocomposites were also used to generate simultaneous UV blocking, self-cleaning and antimicrobial properties of textiles [57, 63, 64]. Similar to the case of the $\mathrm{Ag} / \mathrm{TiO}_{2}$ nanocomposite [61], simultaneous colouration and functional finishing of the cotton fabric was carried out with the use of $\mathrm{Ag} / \mathrm{ZnO}$ nanocomposite colloids under ultrasound irradiation, and vivid coloured multifunctional cotton fabric samples were prepared [63]. The photocatalytic activity of $\mathrm{ZnO}$ in the presence of $\mathrm{Ag}$ did not cause colour fading of the treated samples irrespective of the colour of the Ag NPs, which was very similar to the results obtained for the $\mathrm{Ag} / \mathrm{TiO}_{2}$ nanocomposite. The results also revealed that the presence of $\mathrm{ZnO}$ increased the UPF value of the treated cotton sample, which was lower than that provided by $\mathrm{TiO}_{2}$ at the same concentration. Furthermore, $\mathrm{ZnO}$ exhibited significantly higher antibacterial activity compared with $\mathrm{TiO}_{2}$ at the same concentration. Moreover, the presence of Ag in the nanocomposite enhanced the UPF value and provided the biocidal activity of the finish similar to the $\mathrm{Ag} / \mathrm{TiO}_{2}$ nanocomposite.

Outstanding durable multifunctional properties of cotton/wool and viscose/wool blended fabrics were obtained by the application of $\mathrm{ZnO}$ and $\mathrm{Ag}$ NPs in the presence of citric acid (CA), which was used as a crosslinking agent, and succinic acid (SC), which was used as an esterifying agent, and a catalyst via the pad-dry-microwave fixation procedure [57]. The presence of CA and SC increased the content of $\mathrm{Ag}$ and $\mathrm{ZnO}$ NPs on the fabric samples due to electrostatic attraction, which consequently improved the antibacterial activity and UV blocking properties of the coating in comparison to the fabric treated without the presence of carboxylic acids. A synergistic effect of applying $\mathrm{Ag} / \mathrm{ZnO} \mathrm{NPs}$ was observed. The multifunctionality of the fabric was also increased by the presence of CA, which represents a non-formaldehyde-containing product for durable press finishing because it can significantly increase the wrinkle recover ability and improved the easycare properties of fabrics.

Another multifunctionality of high added value textiles is their simultaneous superhydophobicity and UV blocking properties, which are important for sportswear, high-altitude and military clothing, covering materials and water-oil filters. Although superhydrophobic UV protected textiles have already been created by the application of a $\mathrm{TiO}_{2} \mathrm{NP}$ dispersion prepared with the use of ultrasonification [49, 65], the preparation of coatings with a combination of fluorinated acrylic copolymers, polyvinyl-, alkyland perfluoroalkyl-functionalised silsesquioxanes as well as polydimethylsiloxane (PDMS) with different MO NPs still remains the main route for controlling the chemical structure and roughness of the fibre surface $[9,34,66-69,71]$.

By using a combination of electrospinning and a two-step doctor-blading coating, polyacrylonitrile/ polyurethane nanofibres with the incorporated $\mathrm{TiO}_{2}$ NPs were produced and afterwards coated with 2-hydroxy-4-n-octoxybenzophenone and fluorinated acrylic copolymer [9]. The membrane prepared from the treated nanofibres presented double UV resistance, water and oil repellency and waterproofbreathable functionality.

$\mathrm{TiO}_{2}$ NPs were also applied to cotton fabric in combination with polyvinylsilsesquioxane, a crosslinking agent with a hydrophobic character, by the twotimes pad-dry-cure procedure [66]. The composite coating consisted of large-sized nano- $\mathrm{TiO}_{2}$ aggregates embedded in the polyvinylsilsesquioxane films by $\mathrm{Ti}-\mathrm{O}-\mathrm{Si}$ covalent bonds, which increased the surface roughness of the hydrophobic cotton surface exhibiting excellent UV blocking property and superhydrophobicity without damaging the mechanical properties. Namely, three-dimensional chemical cross-links among the coating and cellulose significantly increased the fabric tensile strength.

To mimic the superhydrophobic lotus leaf in nature, a $\mathrm{ZnO}$ nanorod array with an $\mathrm{SiO}_{2}$ shell was adhered to cotton fabric and then modified by an alkylsilsesquioxane monolayer [70]. Although the insulating $\mathrm{SiO}_{2}$ shell effectively suppressed the photoactivity of the 
$\mathrm{ZnO}$ nanorods, the alkylsilsesquioxane-modified $\mathrm{ZnO} / \mathrm{SiO}_{2}$ nanorod array provided the cotton fabric with an ultrahigh UPF value and durable superhydrophobic properties, even under prolonged UV radiation.

Perfluoroalkylsilsesquioxane was used for subsequent modification of cotton fabric previously coated by a dense film of $\mathrm{CeO}_{2}$ [67]. The incorporation of $\mathrm{CeO}_{2}$ particles can cause surface roughness because of the enhanced hydrophobic properties of perfluoroalkylsilsesquioxane, although it also resulted in a good UV protection property.

Two different cost-effective and scalable strategies were used to create UV blocking and superhydrophobic coatings using a combination of $\mathrm{ZnO}$ and PDMS. The first one included the construction of multi-layered PDMS-ZnO-PDMS composite coating on cotton fabric via deposition of adhesive layer of PDMS, which was followed by the subsequent deposition of $\mathrm{ZnO}$ NPs to enhance the surface roughness and a second PDMS layer to provide for water repellency [68]. In addition to the multifunctional properties, the treated fabric exhibited superior anti-abrasion and excellent laundering durability and was highly efficient for repetitive and versatile oil-water separation. The second approach included simple dip-coating, dropping, spinning or spraying application procedures of a prepared solution containing PDMS and ZnO NPs to polyester fabric [69]. The developed ultra-robust superhydrophobic fabric showed high repellency against water, strong acids, strong alkali and saturated salt solutions. The UV resistance of PDMS preserved the super hydrophobicity even after a long period of UV illumination. The uniform distribution of $\mathrm{ZnO}$ in the coating provided a high UV blocking effect for the fabric.

PDMS was also used in combination with CuS on cotton fabric [34]. In this research, the flower-like $\mathrm{CuS}$ was first synthesised via the solvothermal method, then dispersed in sol in combination with PDMS and applied to cotton fabric by the dip-cure method. In addition to its excellent UV blocking properties, the flower-like CuS, which consisted of self-assembled nanosheets with abundant mesopores between the nanosheets, provided a hierarchical rough surface topography that enhanced the water repellent properties of PDMS. The coating exhibited high washing durability and caused a negligible reduction in the mechanical properties of the cotton fabric.
To impart multifunctional UV blocking, selfcleaning, antimicrobial and electrical conductivity properties, graphene, graphene oxide (GO), Ag and antimony $(\mathrm{Sb})$ were used in combination with MOs NPs. The $\mathrm{GO} / \mathrm{TiO}_{2}$ nanocomposites were prepared by mixing and sonification of both components in a sol, which was subsequently applied to cotton fabric by the dip-drying method [71]. The synergistic UV absorption of $\mathrm{TiO}_{2}$ and GO provided a good UV blocking property to the fabric. The presence of GO in the $\mathrm{GO} / \mathrm{TiO}_{2}$ nanocomposite enhanced the photocatalytic efficiency of the coating, resulting in the increased photodegradation of the dye stain as well as the antimicrobial activity of the treated fabric. Furthermore, the photoinduced electrons in $\mathrm{TiO}_{2}$ under UV radiation enhanced the reduction of oxygen functional groups from the GO, thus leading to improved electrical conductivity.

To develop UV blocking, electrical conductivity and high thermopower properties on cotton fabric, a $\mathrm{ZnO}$ and $\mathrm{Sb} / \mathrm{Ag} / \mathrm{ZnO}$ composite coating was created by the in situ solvothermal growth technique [64]. The $\mathrm{Ag} / \mathrm{ZnO}$ composite imparted an excellent $\mathrm{UPF}$ value to the coated fabric, the $\mathrm{Sb} / \mathrm{Ag} / \mathrm{ZnO}$ composite increased the electrical conductivity, and the intergranular crystal structure of $\mathrm{Ag} / \mathrm{ZnO}$ composite converted the cotton fabric from an insulator into a relatively high thermopower conductor, which is beneficial for the manufacturing of wearable electronic device material.

Graphene/Ag nanocomposites have also been recognised as an effective conductive and UV blocking material for polyester surface modification [36]. The coating was prepared in two stages that included the application of GO via an immersion-drying procedure and its chemical reduction into graphene nanosheets, which was followed by the in situ synthesis of Ag NPs to the graphene coated polyester fabric. The UV protection of the coating was provided by the UV absorption ability of the graphene nanosheets, and it was significantly improved in the presence of small amount of Ag NPs. Both the graphene nanosheets and Ag NPs also formed a conductive network, resulting in excellent electrical conductivity. The coated polyester showed excellent mechanical properties, including flexibility and stretchability, which provided the opportunity to use this material as electrodes in supercapacitors, solar cells and sensors. 
To provide UV resistance and consequently improve the tensile strength of fabric under UV ageing, $\gamma$-methacryloxypropyl trimethoxysilane and illite, a natural clay with superior film-forming activity, were used to prevent photocatalytic degradation of textile fibres due to the inherent photoactivity of $\mathrm{TiO}_{2}$ [72, 73]. A composite polyethylene fabric was prepared by radiation-induced graft polymerisation of $\gamma$-methacryloxypropyl trimethoxysilane followed by the subsequent co-hydrolysis of the graft chains with tetrabutyl titanate to create $\mathrm{TiO}_{2}$ NPs. [72]. In the composed two-layered coating, the inner part consisted of an organically modified solsesquioxane layer to protect the textile fibres against photodegradation and the outer part consists of $\mathrm{TiO}_{2}$ NPs to absorb UV radiation. The treated fabric exhibited much higher thermal resistance and significantly better mechanical properties after UV radiation than the untreated fabric.

To suppress $\mathrm{TiO}_{2}$ photocatalytic activity, $\mathrm{TiO}_{2} \mathrm{NPs}$ were loaded onto the surface of illite microlayers in a hydrothermal reaction, and the as-prepared solution was then applied to cotton fabric via ultrasonification and drying [73]. The results showed that illite itself reflected part of UV light and therefore enhanced the UV blocking action of the $\mathrm{TiO}_{2}$ NPs in the coating. Furthermore, the illite ensured that $\mathrm{TiO}_{2}$ existed in NP form and increased the reflection and scattering of UV light. As a result, only small amount of UV light reached the fibres, thereby maintaining the mechanical properties of the fabric, even after long-term UV radiation.

New hybrid NPs consisting of nano turbostatic boron nitride and polydopamine shells on a $\mathrm{CeO}_{2}$ core were synthesized and chemically grafted to aramid fibres to improve their UV resistance [74]. The double core-shell structure significantly reduced the photocatalytic activity and obviously improved the UV blocking effect of $\mathrm{CeO}_{2}$. The modified fibres had excellent thermal stability and mechanical properties.

Furthermore, the unique properties of graphenebased materials, i.e. UV absorption capabilities without photocatalytic activity and excellent mechanical and chemical properties, enabled their use as a weathering stabiliser of polymeric materials [35]. Namely, the incorporation of GO into polyurethane coating significantly improved the weathering resistance of the coating, and the stabilising performance was much more effective compared with that of organic UV absorbers.
To improve and/or impart functional properties to cotton and cotton/polyester fabrics, $\mathrm{TiO}_{2}, \mathrm{ZnO}$ and $\mathrm{ZrO}_{2}$ NPs were combined with conventional organic finishing agents, i.e., modified N-dimethyloldihydroxyethylene urea as an easy-care agent, aminomodified PDMS as a softener, oxanilide-based compounds as a reactive UV absorber, nitrogen phosphate as a flame retardant agent, fluorinated acrylic copolymer as a water, oil and stain repellent agent, as well as $\mathrm{Ag}$ as an antimicrobial agent, and the textile substrates were applied using the pad-dry-cure procedure [31]. The results demonstrated that a synergistic effect occurred between the MO NPs and conventional organic agents in the coatings, thus suggesting that these finishing formulations can be used for the production of multifunctional textiles with outstanding performance and protective properties.

\section{Ecological concerns associated with UV protection finishes and potential human health effects}

\subsection{Organic aromatic compounds}

Over the past decade, the application of organic UV absorbers has steadily increased. These products are used in various cosmetic products to provide protection to skin and hair against harmful UV radiation or merely to expand the shelf life of beauty products. An increasing number of materials contain organic UV absorbers, including textiles and plastics [75]. Therefore, during the life cycle of organic UV absorbers, their entry into the environment is inevitable. These substances have been found in surface waters, wastewater, drinking water, soil, sludge, fish and the human body [75]. Most organic UV filters based on p-aminobenzoic acid, benzophenone, cinnamate and salicylate have been assessed for multiple hormonal activities as well as for their effects on reproduction and fertility [75]. However, in the aquatic environment, predicted no-effect concentrations of benzophenone- 3 and benzophenone- 4 were found to be lower than those previously detected [76], indicating that the ecological risk of these substances remains low. Nevertheless, in ecological risk assessments, the potential biomagnification of organic UV absorbers should not be ignored. Because of their high lipophilicity and biological persistence, these substances have been shown to accumulate in the food chain. Therefore, 
in a recent study, the occurrence of eight organic UV filters was assessed in fish from four Iberian river basins [77], and the accumulation of benzophenone-3, ethylexyl methoxycinnamate and octocrylene was observed. When these chemicals accumulate, biomagnification is of crucial importance since higher levels of observed organic UV absorbers were detected in predator species, which occupy a higher position in the trophic chain.

The synergistic or antagonistic activities of multimixtures of UV absorbers also need to be considered when estimating their toxicity. Diaz-Cruz et al [75] performed in an in vivo study in which three-component mixtures of 3-benzylidene camphor, benzophenone- 1 and benzophenone- 2 at different concentrations and relative proportions were assessed for oestrogenic activity, and they showed that generally low concentrations of UV filters in the environment may not produce important oestrogenic effects on their own but may lead to increased oestrogenic activity of other xenoestrogens in a synergistic manner. In addition to their beneficial effects, UV absorbers influence the occurrence of dermatological problems and undesirable oestrogenic and antithyroid effects, which are ascribed to the parent compounds as well as their metabolites [78]. Accordingly, in vivo and in vitro studies showed that DNA damage induced by the presence of p-aminobenzoic acid was caused through the photosensitized formation of pyrimidine cyclobutane dimers and nondimer photoproducts as well as the photoaddition of p-aminobenzoic acid to thymine [79]. Importantly, each of these DNA injuries was correlated to a potential skin cancer incidence. However, as pointed out in review article by Godić [80], fear of the possible carcinogenic effects of organic UV absorbers on the skin is unjustified since most of these products degrade in the upper layers of the epidermis. Rather, their absorption via food in the gastrointestinal tract and possible carcinogenic effects should be of far greater concern. However, despite the potential (eco)toxicity associated with the long-term exposure to organic UV absorbers, their advantages greatly outweigh their potential risks.

\subsection{Metal and MOs NPs}

Rapid development of nanotechnology resulted in a huge production of various metal and MOs NPs, particularly $\mathrm{TiO}_{2}$, followed by $\mathrm{ZnO}$ and $\mathrm{CeO}_{2}$ as the second and third largest to the annual volume discharge, respectively [81]. These NPs are daily used in industrial, agriculture, medical and consumer applications. Therefore, during their life cycle there is a chance of exposure for workers, consumers and the environment. Potential toxicological risks of such exposure cannot be easily predicted or assessed, since NPs has both particulate and molecular identity, which induce different biological or ecological effects. Moreover, as pointed out by Pietroiusti [82] there is an urgent need for development of international standard methods for hazard prediction of NPs. Three key elements in NPs toxicity screening strategy have been outlined [83]: physiochemical characterization, in vitro assays and in vivo studies. Among physiochemical properties particle size and agglomeration state are one of the critical parameters for toxicity. Namely, it is generally assumed that aggregated nanoparticles are less toxic or biologically active, compared when in their nano-form. Besides particle size distribution, their shape, crystal structure, chemical composition and surface properties are also key parameters, when discussing their potential toxicity [84]. The latter can be evaluated by in vitro tests, providing information about in vivo effects of NPs. Accordingly, non-cellular tests as well as cell-based systems are taken into consideration, giving information upon biopersistance, free radical generation or activation of humoral systems. Regarding the in vivo testing of NPs toxicity, two tiers of studies were outlined by Oberdöster and his co-workers [83], i.e. tier 1 studies that are relevant to the concerns upon human exposure and tier 2 studies, which provide information for a complete risk assessment of a certain type of NPs. However, as pointed out by Joo et al [81], to resolve these issues fundamental understanding of the transformation processes, fate, transport and assessment of transformed NPs under various environmental conditions is necessary, bearing in mind that environment is a heterogeneous system, whereas impact of co-existing contaminants must be also considered. Accordingly, mobility of NPs, their diffusion and potential toxicity can be strongly affected by the presence of natural organic matter (i.e. humic substances and fluvic acids), whereby disagglomeration takes place [85]. The presence of different surfactants which are extensively used for the production of NPs in the environment media is also worrying. Namely, different functional groups present in the structure of surfactants may react with NPs and alter their physiochemical properties. 
Two mechanisms have been proposed to explain the toxicity of photocatalytically active $\mathrm{TiO}_{2}$ and $\mathrm{ZnO}$ NPs, i.e., the generation of ROS and release of metal ions, which both lead to cellular inflammation and an oxidative stress response [86]. The intensity of both processes depends on the physiochemical properties of the NPs, which is related to their increased specific surface area compared with that of micron-sized metal particles. Therefore, due to ROS formation, the damaging effects of $\mathrm{TiO}_{2}$ and $\mathrm{ZnO}$ NPs on different aquatic species and bacteria have been reported [87-90]. Undoubtedly, the formation of toxic ROS is induced by UV light. However, Adams and his co-workers [91] reported the inhibitory effect of $\mathrm{TiO}_{2}$ and $\mathrm{ZnO}$ NPs against gram-positive Bacillus subtilis and gram-negative Escherichia coli under dark conditions, suggesting that another mechanism contributes to the toxicity of these NPs, such as the solubility of oxide NPs and release of metal ions, which strongly influences their toxicity. In the case of $\mathrm{ZnO}$ NPs, the water chemistry has an important influence on the aggregation/dissolution process [92], and the solubility of $\mathrm{ZnO}$ NPs can more than double in sea water compared with that of bulk $\mathrm{ZnO}$, thus lead to the increased release of $\mathrm{Zn}^{2+}$ ions. This process is temperature dependent. As observed by Woong [93], the formation of $\mathrm{Zn}^{2+}$ ions from $\mathrm{ZnO}$ NPs decreases as the water temperature increases. Importantly, lowering the water temperature significantly enhances the uptake of natural organic matter and $\mathrm{Zn}^{2+}$ (as a heavy metal surrogate) to the surface of $\mathrm{ZnO}$ NPs [92]. Therefore, altered ZnO NPs are likely to release surface-adsorbed contaminants at elevated temperatures, thus implementing a "Trojan Horse effect" [94]. Accordingly, the direct uptake of $\mathrm{TiO}_{2}$ and $\mathrm{ZnO}$ NPs in a concentration-dependent manner was observed for the model bacterium Salmonella typhimurium, and it demonstrated weak mutagenic and possible carcinogenic potential [84].

Once in the aquatic environment, $\mathrm{CeO}_{2} \mathrm{NPs}$ are highly agglomerative, which keeps the particles' surface area available for interactions with cells or organisms [95]. In this respect, the ecotoxicity of $\mathrm{CeO}_{2}$ NPs against representatives of different trophic levels, i.e., from primary producers to secondary consumers, was studied. The toxic effects against algae and amphibian larvae was proven [96; 95; 97], although $\mathrm{CeO}_{2}$ was not toxic for planktonic crustaceans, midge fly larvae and zebrafish embryos. Compared with $\mathrm{TiO}_{2}$ and $\mathrm{ZnO} \mathrm{NPs}$, the toxicity of $\mathrm{CeO}_{2}$ likely is not related to the generation of ROS or the direct effect of dissolved $\mathrm{Ce}$ or $\mathrm{CeO}_{2} \mathrm{NP}$ uptake. Rather, the harmful effect of $\mathrm{CeO}_{2} \mathrm{NPs}$ was mainly ascribed to the clustering of the particle aggregates around the algal cells as well as to the tendency of $\mathrm{CeO}_{2}$ NPs to aggregate and sediment in the case of amphibian larvae $[96,97]$. Amphibian larvae are filter feeders, and their contamination can occur either by skin contact or water filtration. Since these sarava organisms are the base of the trophic chain, the entry of the $\mathrm{CeO}_{2}$ NPs via the trophic route into secondary consumers is extremely alarming, suggesting possible drastic consequences in the case of biomagnification [97]. The increased toxicity of $\mathrm{CeO}_{2}$ NPs was ascribed to their high stability in aquatic environments as a result of possible elevated surface repulsive forces, which also influenced their decreased removal from water as well as decreased retention in porous media [98].

During the production and use of metal and metal oxide NPs, human exposure is inevitable. There are various routes for entry of NPs, such as from the occupational environment to the worker's body or from different products into a consumer's body. For functionalized textiles, the most frequent exposure route appears to be the inhalation of dust released from the textile during its use and/or by skin contact. $\mathrm{TiO}_{2}$ and $\mathrm{ZnO}$ NPs are considered harmless when exposed to healthy skin $[99,100]$. However, mixed-phase $\mathrm{TiO}_{2}$ (i.e., anatase and rutile) can cause oxidative injury to the skin under sunlight exposure, thus demonstrating more toxic effects to cells than pure phase NPs. Namely, induced by UV radiation, mixed-phased $\mathrm{TiO}_{2}$ NPs caused hierarchical oxidative stress toxicological responses that resulted in human keratinocyte cell death and mouse skin damage. Importantly, without sunlight exposure, mixed-phased $\mathrm{TiO}_{2} \mathrm{NPs}$ did not induce notable toxicity [101].

Upon inhalation, $\mathrm{TiO}_{2}, \mathrm{ZnO}$ and $\mathrm{CeO}_{2} \mathrm{NPs}$ caused an inflammatory effect in human bronchial epithelial cells via oxidative stress $[83$ 102, 103]. In high doses, $\mathrm{ZnO}$ NPs also presented a certain level of cytotoxicity and led to reduced lung cell viability or even cell death. Kim and co-workers [104] performed in vitro assessments and compared the toxicity of $\mathrm{TiO}_{2}, \mathrm{ZnO}$ and $\mathrm{CeO}_{2}$ NPs to human epithelial cells in terms of cell proliferation, cell viability, 
membrane integrity and oxidative stress. Among the tested NPs, $\mathrm{ZnO}$ exhibited the highest cytotoxicity, followed by $\mathrm{TiO}_{2}$ and $\mathrm{CeO}_{2}$, which both showed little adverse effects on cell proliferation and cell viability, although in the case of $\mathrm{TiO}_{2} \mathrm{NPs}$, oxidative stress in a concentration- and time-dependent manner was observed. Nevertheless, when these particles were applied to the fibres, none of the functionalized textile samples were cytotoxic upon exposure to various human cells, thus demonstrating high biocompatibility $[30,46,105]$.

\subsection{Non-metals}

As a representative of a novel class of carbon-based engineered nanomaterials, GO NP production has been constantly increasing and may overtake carbon nanotubes in applications [106]. Despite being a relatively novel material, evidence has demonstrated the cytotoxicity of GO NPs on various types of cells via a number of mechanisms, such as membrane damage, ROS generation, and expression level alterations of several key genes related to apoptosis [107]. Adverse effects against non-mammalian were also determined, and toxicity against Caenorhabditis elegans (C. elegans), a representative of roundworms, has primarily been studied [108-112]. These studies showed impaired functions in the intestine, neurons and reproductive organs upon exposure to GO NPs, which were ascribed to a weakened epidermal barrier as a consequence of peroxidase formation in the epidermis. Accordingly, RNA damage was demonstrated, which promoted the susceptibility to GO toxicity and enhanced GO accumulation [106]. This finding is of particular concern as C. elegans represents an intermediate between unicellular eukaryotes and more complex organisms, such as vertebrates and higher plants, thus showing a possible biomagnification tendency. The in vivo biodistribution of GO NPs was studied by Zhang et al [113], who found that after their intravenous injection in mice, GO NPs predominantly deposited in the lungs over long time period, and they induced pulmonary oedema and granuloma formation in the lung. However, no noticeable organ damage via inflammation was observed for surface-modified GO NPs [114], implying that introducing different polymers and functional groups on the surface of graphene decreases its in vivo toxicity, thus improving graphene's biocompatibility.

\section{Conclusion}

In this review, the most important research directions in the field of UV protection finishing of textiles were presented. In the case of organic UV absorbers, the UV-absorbing bioactive substances have increasingly established as eco-friendly neverending resources of natural finishes. Among them, extracts from various plants, such as Marine macroalgae (seaweeds), Marigold (Tagetes erecta), Aloe Vera and Scutellaria baicalensis Georgi have been applied to textile fibres because of their great UV absorbing potential.

In the case of inorganic UV blockers, the most contemporary research includes the production of textiles with multifunctional UV protection, antimicrobial, water and oil repellent and easy-care properties, electrical conductivity, UV aging resistance, thermal stability and flame retardancy.

Besides the beneficial protective effect of UV protection finishing against harmful UV radiation, the growing use of organic and inorganic UV protection finishes over the last decades have caused environmental concerns since different toxic degradation products of the UV absorbers as well as NPs have been found to be bioaccumulated. These environmental issues dictate professional handling with UV protection finishes.

\section{References}

1. YU, Sung-Lim, LEE, Sung-Keun. Ultraviolet radiation: DNA damage, repair, and human disorders. Molecular and Cellular Toxicology, 2017, 13, 21-28, doi: 10.1007/s13273-017-0002-0.

2. SIVAMANI, Raja K., CRANE, Lori A., DELLAVALLE, Robert $P$. The benefits and risks of ultraviolet (UV) tanning and its alternatives: the role of prudent sun exposure. Dermatolig Clinics, 2009, 27(2), 49-54, doi: 10.1016/j.det.2008. 11.008.

3. D'ORAZIO, John, JARRETT, Stuart, AMAROORTIZ, Alexandra, SCOTT, Timothy. UV radiation and the skin. International Journal of Molecular Sciences, 2013, 14, 12222-12248, doi: 10. 3390/ijms140612222.

4. DAS, Biswa Ranjan. UV Radiation protective clothing. The Open Textile Journal, 2010, 3, 14-21.

5. SCHINDLER, W. D., HAUSER, P. J. Ultraviolet protection finishes. In Chemical finishing of 
textiles. Cambridge : Woodhead Publishing Limited, 2004, pp. 157-164.

6. BODUR, Mehmet Safa, BAKKAL, Mustafa, SONMEZ, Hasret Ece. A Study on Photostabilizer additives on textile fiber reinforced polymer composites: mechanical, thermal, and physical analysis. Polymer Engineering and Science, 2017, doi: 10.1002/pen.

7. RADETIĆ, Maja. Functionalization of textile materials with $\mathrm{TiO}_{2}$ nanoparticles. Journal of Photochemistry and Photobiology C: Photochemistry Reviews, 2013, 16, 62-76, doi: 10.1016/j. photochemrev.2013.04.002.

8. YANG, Hongying, ZHU, Sukang, PAN, Ning. Studying the mechanisms of titanium dioxide as Ultraviolet-blocking additive for films and fabrics by an improved scheme. Journal of Applied Polymer Science, 2004, 92, 3201-3210.

9. XU, Yue, SHENG, Junlu, YIN, Xia, YU, Jianyong, DING, Bin. Functional modification of breathable polyacrylonitrile/polyurethane/TiO2 nanofibrous membranes with robust ultraviolet resistant and waterproof performance. Journal of Colloid and Interface Science, 2017, 508, 508-516, doi: 10.1016/j.jcis.2017.08.055.

10. ZHANG, L., MOU, J. Nano-materials and nanostructure. Beijing : Science Press, 2001, p. 84.

11. ALEBEID, Omer Kamal, ZHAO, Tao. Review on: developing UV protection for cotton fabric. The Journal of The Textile Institute, 2017, 108(12), 2027-2039, doi: 10.1080/00405000. 2017.1311201.

12. WONG, Wai-Yin, LAM, Jimm Kwok-Cheong, KAN, Chi-Wai, POSTLE, Ronald. Ultraviolet protection of weft-knitted fabrics. Textile Progress, 2016, 48(1), 1-54, doi: 10.1080/00405167. 2015. 1126952.

13. GUGUMUS, F. Developments in the UV-stabilisation of polymers. London : Applied Science Publishers, 1979.

14. AKRMAN, Jiri, PRIKRYL, Josef. Application of benzotriazole reactive UV absorbers to cellulose and determining sun protection of treated fabric spectrophotometrically. Journal of Applied Polymer Science, 2008, 108, 334-341, doi: 10.1002/app.

15. CHAKRABORTY, J. N., SHARMA, Vivek, GAUTAM, Preeti. Enhancing UV Protection of cotton through application of novel UV absorbers. Journal of Textile and Apparel, Technology and Managment, 2014, 9(1).
16. STAFFA, Lucas H., AGNELLI, Jose Augusto M., DE SOUZA, Miguel L., BETTINI, Silvia H. P. Evaluation of interactions between compatibilizers and photostabilizers in coir fiber reinforced polypropylene composites. Polymer engineering and science, 2017, 1185, doi: 10. $1002 /$ pen.

17. CZAJKOWSKI, Wojciech, MAMNICKA, Justyna, LOTA, Wieslawa, LEWARTOWSKA, Joanna. Application of reactive UV-absorbers for increasing protective properties of cellulose fabrics during standard laundering process. Fibers and Polymers, 2012, 13(7), 948-953, doi: 10.1007/s12221-012-0948-4.

18. FENG, Yajuan, LI, Daikun, ZHANG, Fengxiu, ZHANG, Guangxian. A novel reactive anti-ultraviolet finishing of cotton fabric based on $\mathrm{N}$ dihydroxy ethylene cyanoguanidine. Textile Research Journal, 2017, 87(14), 1722-1729, doi: 10.1177/0040517516658515.

19. SHEN, Yun, ZHEN, Lili, HUANG, Dan, XUE, Jiang. Improving anti-UV performances of cotton fabrics via graft modification using a reactive UV-absorber. Cellulose, 2014, 21, 37453754, doi: 10.1007/s10570-014-0367-3.

20. JANARTHANAN, M., SENTHIL KUMAR, M. The properties of bioactive substances obtained from seaweeds and their applications in textile industries. Journal of Industrial Textiles, 2018, 48(1), 36-40, doi: 10.1177/1528083717692596.

21. SHABBIR, Mohd, RATHER, Luqman Jamel, MOHAMMAD, Faqeer. Economically viable UV-protective and antioxidant finishing of wool fabric dyed with Tagetes erecta flower extract: Valorization of marigold. Industrial Crops \& Products, 2018, 119, 277-282, doi: 10.1016/j. indcrop.2018.04.016.

22. SUBRAMANI, Karthik, SHANMUGAM, Balu Kolathupalayam, RANGARAJ, Suriyaprabha, PALANISAMY, Manivasakan, PERIASAMY, Prabu, VENKATACHALAM, Rajendran. Screening the UV-blocking and antimicrobial properties of herbal nanoparticles prepared from Aloe vera leaves for textile applications. IET Nanobiotechnology, 2017, 1751-8741, doi: 10.1049/iet-nbt.2017.0097.

23. ZHOU, Yuyang, YANG, Zhi-Yi, TANG, RenCheng. Bioactive and UV protective silk materials containing baicalin - The multifunctional plant extract from Scutellaria baicalensis Georgi. 
Materials Science and Engineering, 2016, C 67, 336-344, doi: 10.1016/j.msec.2016.05.063.

24. KOH, Eunmi, HONG, Kyung Hwa. Functional fabric treatment using tannic acid and extract from purple-fleshed sweet potato. Textile Research Journal, 2017, 87(7), 790-798, doi: 10. 1177/0040517516639829.

25. SAEWAN, Nisakorn, JIMTAISONG, Ampa. Photoprotection of natural flavonoids. Journal of Applied Pharmaceutical Science, 2013, 3(09), 129-141, doi: 10.7324/JAPS.2013.3923.

26. ADEEL, Shahid, GULZAR, Tahsin, AZEEM, Muhammad, REHMAN, Fazal-ur, SAEED, Muahammad, HANIF, Iram, IQBAL, Naeem. Appraisal of marigold flower based lutein as natural colourant for textile dyeing under the influence of gamma radiations. Radiation Physics and Chemistry, 2017, 130, 35-39, doi: 10. 1016/j.radphyschem.2016.07.010.

27. GHAYEMPOUR, S., MONTAZER, M., MAHMOUDI RAD, M. Simultaneous encapsulation and stabilization of Aloe vera extract on cotton fabric for wound dressing application. Royal Society of Chemistry, 2016, 6, 111895-111902, doi: $10.1039 / \mathrm{c} 6 \mathrm{ra} 22485 \mathrm{~g}$.

28. MOAFI, Hadi Fallah, SHOJAIE, Abdollah Fallah, ZANJANCHI, Ali. The comparative study of photocatalytic self-cleaning properties of synthesized nanoscale titania and zirconia onto polyacrylonitrile fibers. Journal of Applied Polymer Science, 2010, 118, 2062-2070, doi: 10.1002/app.32463.

29. DADVAR, Saeed, TAVANAI, Hossein, MORSHED, Mohammad. UV-protection properties of electrospun polyacrylonitrile nanofibrous mats embedded with $\mathrm{MgO}$ and $\mathrm{Al} 2 \mathrm{O} 3$ nanoparticles. Journal of Nanoparticle Research, 2011, 13, 5163-5169, doi: 10.1007/s11051-011-0499-4.

30. LU, Zhisong, MAO, Cuiping, MENG, Mei, LIU, Sangui, TIAN, Yunli, YU, Ling, SUN, Bai, LI, Chang Ming. Fabrication of $\mathrm{CeO} 2$ nanoparticle-modified silk for UV protection and antibacterial applications. Journal of Colloid and Interface Science, 2014, 435, 8-14, doi: 10.1016/j. jcis.2014.08.015.

31. IBRAHIM, N. A., EL-ZAIRY, E. M., EID, B. M., EMAM, E., BARKAT, S. R., A new approach for imparting durable multifunctional properties to linen-containing fabrics. Carbohydrate Polymers, 2017, 157, 1085-1093, doi: 10.1016/j. carbpol.2016.10.074.
32. KE, Zhang, MIAO, Du, LEI, Hao, JIANPING, Meng, JINING, Wang, XIAOPENG, Liu, ZHEJUN, Deng, JIE, Min, BO, Zhao. Thermal stability test and ageing mechanisms study of different solar selective absorbing coatings. Surface \& Coatings Technology, 2017, 323, 65-71, doi: 10.1016/j.surfcoat.2016.08.092.

33. TIAN, Mingwei, HU, Xili, QU, Lijun, DU, Minzhi, ZHU, Shifeng, SUN, Yaning, HAN, Guangting. Ultraviolet protection cotton fabric achieved via layer-by-layer self-assembly of graphene oxide and chitosan. Applied Surface Science, 2016, 377, 141-148, doi: 10.1016/j. apsusc.2016.03.183.

34. XU, Lihui, ZHANG, Xuanyu, SHEN, Yong, DING, Ying, WANG, Liming, SHENG, Yu. Durable superhydrophobic cotton textiles with Ultraviolet-blocking property and photocatalysis based on flower-like copper sulfide. Industrial and Engineeing Chemistry Research, 2018, 57, 6714-6725, doi: 10.1021/acs.iecr.8b00254.

35. HASANI, M., MHDAVIAN, M., YARI, H., RAMEZANZADEH, B. Versatile protection of exterior coatings by the aid of graphene oxide nanosheets; comparison with conventional UV absorbers. Progress in Organic Coatings, 2017, 116, 90-101, doi: 10.1016/j.porgcoat.2017. 11.020.

36. OUADIL, B., CHERKAOUI, O., SAFI, M., ZAHOUILY, M. Surface modification of knit polyester fabric for mechanical, electrical and UV protection properties by coating with graphene oxide, graphene and graphene/silver nanocomposites. Applied Surface Science, 2017, 414, 292-302, doi: 10.1016/j.apsusc.2017.04.068.

37. JIANG, Shouxing, MIAO, Dagang, XU, Jiangtao, SHANG, Songmin, NING, Xin, ZHU, Ping. Preparation and characterization of shielding textiles to prevent infrared penetration with $\mathrm{Ag}$ thin films. Journal of Materials Science Mater Electron, 2017, 28, 3542-3547, doi: 10.1007/ s10854-016-5955-6.

38. WIENER, J., CHLÁdOVÁ, A., SHAHIDI, S., PETEROVÁ, L. Effect of UV irradiation on mechanical and morphological properties of natural and synthetic fabric before and after nanoTio2 padding. Autex Research Journal, 2017, 17(4), 370-378, doi: https://doi.org/10.1515/ aut-2017-0002.

39. HOSSAIN, Mohammed Asif, RAHMAN, Moshiur. A Review of nano particle usage on 
textile material against Ultra Violet radiation. Journal of Textile Science and Technology, 2015, 1, 93-100, doi: 10.4236/jtst.2015.13010.

40. REINOSA, Julian Jimenez, DOCIO, Carmen Maria Alvarez, RAMIREZ, Victor Zapata, LOZANO, Jose Francisco Fernandez. Hierarchical nano ZnO-micro $\mathrm{TiO} 2$ composites: High UV protection yield lowering photodegradation in sunscreens. Ceramics International, 2018, 44(3), 2827-2834, doi: 10.1016/j.ceramint.2017.11.028.

41. OLLER, I., GERNJAK, W., MALDONADO, M. I., PEREZ-ESTRADA, L. A., SANCHEZ-PEREZ, J. A., MALATO, S. Solar photocatalytic degradation of some hazardous water-soluble pesticides at pilot-plant scale. Journal of Hazardous Materials, 2006, 138(3), 2006, 507-517, doi: 10.1016/j.jhazmat.2006.05.075.

42. LI, M., LI, G., JIANG, J., ZHANG, Z., DAI, X., MAI, K. Ultraviolet resistance and antimicrobial properties of $\mathrm{ZnO}$ in the polypropylene materials: a review. Journal of Material Science and Technology, 2015, 31, 2015, 331-339, doi: 10. 1016/j.jmst.2014.11.022.

43. SMIJS, Threes G., PAVEL, Stanislav. Titanium dioxide and zinc oxide nanoparticles in sunscreens: focus on their safety and effectiveness. Nanotechnology, Science and Applications, 2011, 4, 95-112, doi: 10.2147/NSA.S19419.

44. TAO, Xuchen, HU, Chenggong, XU, Zhenzhen, ZHU, Meifang, XIE, Maobin, LI, Yi, LI, Gang. Development and antiultraviolet properties of epoxidized styrene- butadiene-styrene nanofibers loaded with nanometer titania dioxide. Journal of Industrial Textiles, 2017, 46(8), 1715-1724, doi: $10.1177 / 1528083716647200$.

45. MISHRA, Anu, BUTOLA, Bhupendra Singh. Development of cotton fabrics with durable UV protective and self-cleaning property by deposition of low TiO2 Levels through sol-gel process. Photochemistry and Photobiology, 2018, 94, 503-511, doi: 10.1111/php.12888.

46. EL-NAGGAR, Mehrez E., SHAARAWY, S., HEBEISH, A. A. Multifunctional properties of cotton fabrics coated with in situ synthesis of zinc oxide nanoparticles capped with date seed extract. Carbohydrate Polymers, 2018, 181, 307-316, doi: 10.1016/j.carbpol.2017.10.074.

47. SHAHEEN, Th. I., EL-NAGGAR, Mehrez, ABDELGAWAD, Abdelrahman M., HEBEISH, A. Durable antibacterial and UV protections of in situ synthesized zinc oxide nanoparticles onto cotton fabrics. International Journal of Biological Macromolecules, 2016, 83, 426-432, doi: 10. 1016/j.ijbiomac.2015.11.003.

48. NOORIAN, Seyyed Abbas, HEMMATINEJAD, Nahid, BASHARI, Azadeh. One-pot synthesis of $\mathrm{Cu} 2 \mathrm{O} / \mathrm{ZnO}$ nanoparticles at present of folic acid to improve UV-protective effect of cotton fabrics. Photochemistry and Photobiology, 2015, 91, 510-517, doi: 10.1111/php. 12420.

49. ZHOU, Shunli, WANG, Feng, BALACHANDRAN, Subramanian, LI, Gen, ZHANG, Xiuqin, WANG, Rui, LIU, Peng, DING, Yanfen, ZHANG, Shimin, YANG, Mingshu. Facile fabrication of hybrid PA6-decorated $\mathrm{TiO}_{2}$ fabrics with excellent photocatalytic, antibacterial, UV light-shielding, and super hydrophobic properties. New Journal of Chemistry, 2017, 7, 5237552381, doi: 10.1039/c7ra09613e.

50. LI, Shuhui, ZHU, Tianxue, HUANG, Jianying, GUO, Qingqing, CHEN, Guoqiang, LAI, Yuekun. Durable antibacterial and UV-protective $\mathrm{Ag} /$ TiO2@ fabrics for sustainable biomedical application. International Journal of Nanomedicine, 2017, 12, 2593-2606, doi: 10.2147/IJN.S132035.

51. MA, Qi, WANG, Bin, LV, Junwei, LI, Yuntao, LI, Hui, ZHAO, Chunxia. Preparation of $\mathrm{PBO} / \mathrm{ZnO}$ fibers by hydrothermal synthesis method and its properties. Materials Research Express, 2017, 4, 085301, doi: 10.1088/2053-1591/aa7fcc.

52. MISHRA, Anu, BUTOLA, Bhupendra Singh. Deposition of $\mathrm{Ag}$ doped $\mathrm{TiO} 2$ on cotton fabric for wash durable UV protective and antibacterial properties at very low silver concentration. Cellulose, 2017, 24, 3555-3571, doi: 10.1007/ s10570-017-1352-4.

53. THI, Viet Ha Tran, LEE, Beyeong-Kyu. Development of multifunctional self-cleaning and UV blocking cotton fabric with modification of photoactive $\mathrm{ZnO}$ coating via microwave method. Journal of Photochemistry and Photobiology A: Chemistry, 2017, 338, 13-22, doi: 10.1016/j. jphotochem.2017.01.020.

54. SUBBIAH, Dinesh Kumar, MANI, Ganesh Kumar, BABU, K. Jayanth, DAS, Apurba, RAYAPPAN, John Bosco Balaguru. Nanostructured ZnO on cotton fabrics - A novel flexible gas sensor \& UV filter. Journal of Cleaner Production, 2018, 194, 372-382, doi: 10.1016/j.jclepro.2018. 05.110. 
55. JAZBEC, Katja, ŠALA, Martin, MOZETIČ, Miran, VESEL, Alenka, GORJANC, Marija. Functionalization of cellulose fibres with oxygen plasma and $\mathrm{ZnO}$ nanoparticles for achieving UV protective properties. Journal of Nanomaterials, 2015, 1-9, doi: 10.1155/2015/346739.

56. RERAEI, Farzad, MALEKNIA, Laleh, VALIPOUR, Peyman, FARD, Ghazaleh Chizari. Improvement properties of nylon fabric by corona pre-treatment and nano coating. The Journal of The Textile Institute, 2016, 107(10), 1223-1231, doi: 10.1080/00405000.2015.1100394.

57. IBRAHIM, Nabil A., EMAM, El-Amir M., EID, Basma M., TAWFIK, Tawfik M. An Eco-friendly multifunctional nano-Finishing of cellulose/ wool blends. Fibers and Polymers, 2018, 19(4), 797-804, doi: 10.1007/s12221-018-7922-8.

58. NOURBAKHSH, Shirin, MONTAZER, Majid, KHANDAGHABADI, Zoha. Zinc oxide nano particles coating on polyester fabric functionalized through alkali treatment. Journal of Industrial Textiles, 2018, 47(6), 1006-1023, doi: $10.1177 / 1528083716657819$.

59. GORJANC, Marija, ŠALA, Martin. Durable antibacterial and UV protective properties of cellulose fabric functionalized with $\mathrm{Ag} / \mathrm{TiO} 2$ nanocomposite during dyeing with reactive dyes. Cellulose, 2016, 23, 2199-2209, doi: 10.1007/ s10570-016-0945-7.

60. RANA, Masud, HAO, Bin, MU, Lei, CHEN, Lin, MA, Peng-Cheng. Development of multi-functional cotton fabrics with $\mathrm{Ag} / \mathrm{AgBreTiO} 2$ nanocomposite coating. Composites Science and Technology, 2016, 122, 104-112, doi: 10.1016/j. compscitech.2015.11.016.

61. JAFARI-KIYAN, Akram, KARIMI, Loghman, DAVODIROKNABADI, Abolfazl. Producing colored cotton fabrics with functional properties by combining silver nanoparticles with nano titanium dioxide. Cellulose, 2017, 24, 3083-3094, doi: 10.1007/s10570-017-1308-8.

62. KOWALCZYK, Dorota, BRZEZINSKI, Stefan, KAMINSKA, Irena. Multifunctional nanocoating finishing of polyester/cotton woven fabric by the sol-gel method. Textile Research Journal, 2018, 88(8), 946-956, doi: 10.1177/ 0040517517693979.

63. AVAZPOUR, Soniya, KARIMI, Loghman, ZOHOORI, Salar. Simultaneous coloration and functional finishing of cotton fabric using $\mathrm{Ag} /$
$\mathrm{ZnO}$ nanocomposite. Coloration Technology, 2017, 133, 423-430, doi: 10.1111/cote.12296.

64. VELUSWAMY, Pandiyarasan, SUHASINI, Sathiyamoorthy, KHAN, Faizan, GHOSH, Aranya, ABHIJIT, Majumdar, HAYAKAWA, Yasuhiro, IKEDA, Hiroya. Incorporation of $\mathrm{ZnO}$ and their composite nanostructured material into a cotton fabric platform for wearable device applications. Carbohydrate Polymers, 2017, 157, 1801-1808, doi: 10.1016/j.carbpol.2016.11.065.

65. ATTIA, Nour F., MOUSSA, Mona, SHETA, Aida M. F., TAHA, Rehab, GAMAL, Heba. Effect of different nanoparticles based coating on the performance of textile properties. Progress in Organic Coatings, 2017, 104, 72-80, doi: 10. 1016/j.porgcoat.2016.12.007.

66. CHEN, Dongzhi, MAI, Zhonghua, LIU, Xin, YE, Deizhan, ZHANG, Hongwei, YIN, Xianze, ZHOU, Yingshan, LIU, Min, XU, Weilin. UVblocking, superhydrophobic and robust cotton fabrics fabricated using polyvinylsilsesquioxane and nano-TiO2. Cellulose, 2018, 25, 3635-3647, doi: 10.1007/s10570-018-1790-7.

67. DUAN, Wei, XIE, Anjian, SHEN, Yuhua, WANG, Xiufang, WANG, Fang, ZHANG, Ye, LI, Jialin. Fabrication of superhydrophobic cotton fabrics with UV protection based on $\mathrm{CeO}_{2}$ particles. Industrial and Engineering Chemistry Research, 2011, 220, 4441-4445, doi: 10.1021/ ie101924v.

68. ZHU, Tianxue, LI, Shuhui, HUANG, Jianying, MIHAILISA, Manuela, LAI, Yuekun. Rational design of multi-layered superhydrophobic coating on cotton fabrics for UV shielding, selfcleaning and oil-water separation. Materials and Design, 2017, 134, 342-351, doi: 10.1016/ jmatdes2017.08.071.

69. REN, Guina, SONG, Yuanming, LI, Xiangming, WANG, Bo, ZHOU, Yanli, WANG, Yuyan, GE, Bo, ZHU, Xiaotao. A simple way to an ultra-robust superhydrophobic fabric with mechanical stability, UV durability, and UV shielding property. Journal of Colloid and Interface Science, 2018, 522, 57-62, doi: 10.1016/j.jcis.2018.03.038.

70. WANG, Lingling, ZHANG, Xintong, LI, Bing, SUN, Panpan, YANG, Jikai, XU, Haiyang, LIU, Yichun. Superhydrophobic and Ultravioletblocking cotton textiles. American Chemical Society, 2011, 3, 1277-1281, doi: 10.1021/ am200083z. 
71. KARIMI, Loghman, YAZDANSHENAS, Mohammad Esmail, KHAJAVI, Ramin, RASHIDI, Abosaeed, MIRJALILI, Mohammad. Functional finishing of cotton fabrics using graphene oxide nanosheets decorated with titanium dioxide nanoparticles. The Journal of the Textile Institute, 2016, 107(9), 1122-1134, doi: 10.1080/00405000. 2015.1093311.

72. HU, Jiangato, GAO, Qianhong, XU, Lu, ZHANG, Mingxing, XING, Zhe, GUO, Xiaojing, ZHANG, Kuo, WU, Guozhong. Significant improvement in thermal and UV resistances of UHMWPE fabric through in situ formation of polysiloxane-TiO2 hybrid layers. ACS Applied Materials and Interfaces, 2016, 8, 23311-23320, doi: 10.1021/acsami.6b04914.

73. JU, Hao, JIANG, Yinshan, XUE, Bing, XU, Yuanjun, GUO, Honggang, HUO, Mingyuan, LI, Fangfei. UV shielding performance of illite/ $/ \mathrm{TiO}_{2}$ nanocomposites. New Journal of Chemistry, 2018, 42, 9260-9268, doi: 10.1039/ c7nj4740a.

74. CAI, Hua, SHEN, Da, YUAN, Li, GUAN, Qingbao, GU, Aijuan, LIANG, Guozheng. Developing thermally resistant polydopamine@nano turbostratic BN@CeO2 double core-shell ultraviolet absorber with low light-catalysis activity and its grafted high performance aramid fibers. Applied Surface Science, 2018, 452, 389-399, doi: 10.1016/j.apsusc.2018.05.035.

75. DIAZ-CRUZ, M. Silvia, BARCELO, Damia. Chemical analysis and ecotoxicological effects of organic UV-absorbing compounds in aquatic ecosystems. Trends in Analytical Chemistry, 2009, 28(6), 709-717, doi: 10.1016/j.trac.2009. 03.010.

76. DU, Yang, WANG, Wen-Qian, PEI, Zhou-Tao, AHMAD, Fahmi, XU, Rou-Rpu, ZHANG, YiMin, SUN, Li-Wei. Acute toxicity and ecological risk assessment of benzophenone-3 (BP-3) and benzophenone-4 (BP-4) in Ultraviolet (UV)-filters. International Journal of Environmental Research and Public Health, 2017, 14(1414), 1-15, doi: 10.3390/ijerph14111414.

77. GAGO-FERRERO, Pablo, DIAZ-CRUZ, M. Silvia, BARCELO, Damia. UV filters bioaccumulation in fish from Iberian river basins. Science of the Total Environment, 2015, 518-519, 518-525, doi: 10.1016/j.scitotenv.2015.03.026.

78. TSOUMACHIDOU, Sophia, LAMBROPOULOU, Dimitra, POULIOS, Ioannis. Homogeneous photocatalytic oxidation of UV filter para-aminobenzoic acid in aqueous solutions. Environmental Science and Pollution Research, 2017, 24, 1113-1121, doi: 10.1007/s11356-016-7434-2.

79. CHRETIEN, Michelle N., MIGAHED, Lamlaa, SCAIANO, J. C. Protecting the Protectors: Reducing the biological toxicity of UV sunscreens by zeolite encapsulation. Photochemistry and Photobiology, 2006, 82, 1606-1611, doi: 10. 1562/2006-07-11-RA-967.

80. GODIČ, Aleksandar. Sredstva za zaščito pred soncem. Zdravniški Vestnik, 2012, 81, 867-875.

81. JOO, Sung Hee, ZHAO, Dongye. Environmental dynamics of metal oxide nanoparticles in heterogeneous systems: A review. Journal of Hazardous Materials, 2017, 322, 29-47, doi: 10.1016/j.jhazmat.2016.02.068.

82. PIETROIUSTI, Antonio, STOCKMANN-JUVALA, Helene, LUCARONI, Francesca, SAVOLAINEN, Kai. Nanomaterial exposure, toxicity, and impact on human health. WIREs Nanomedicine and Nanobiotechnology, 2018, 10(1513), 1-21, doi: 10.1002/wnan.1513.

83. OBERDORSTER, Gunter, MAYNARD, Andrew, DONALDSON, Ken, CASTRANOVA, Vincent, FITZPATRICK, Julie, AUSMAN, Kevin, CARTER, Janet, KARN, Barbara, KREYLING, Wolfgang, ALI, David, OLIN, Stephen, MONTEIRO-RIVIERE, Nancy, WARHEIT, David, YANG, Hong. Principles for characterizing the potential human health effects from exposure to nanomaterials: elements of a screening strategy. Particle and Fibre Toxicology, 2005, 2(8), 1-35, doi: 10.1186/17438977-2-8.

84. KUMAR, Ashutosh, PANDEY, Alok K., SINGH, Shashi S., SHANKER, Rishi, DHAWAN, Alok. Cellular uptake and mutagenic potential of metal oxide nanoparticles in bacterial cells. Chemosphere, 2011, 83, 1124-1132, doi: 10. 1016/j.chemosphere.2011.01.025.

85. LOOSLI, Frederic, LE COUSTUMER, Philippe, STOLL, Serge. Effect of natural organic matter on the disagglomeration of manufactured $\mathrm{TiO}_{2}$ nanoparticles. Royal Society of Chemistry, 2014, 1, 154-160, doi: 10.1039/c3en00061c.

86. KAHRU, Anne, DUBOURGUIER, HenriCharles, BLINOVA, Irina, IVASK, Angela, KASEMETS, Kaja. Biotests and biosensors for ecotoxicology of metal oxide nanoparticles: A 
minireview. Sensors, 2008, 8, 5153-5170, doi: $10.3390 /$ s8085153.

87. LI, Fengmin, LIANG, Zhi, ZHENG, Xiang, ZHAO, Wei, WU, Miao, WANG, Zhenyu. Toxicity of nano-TiO2 on algae and the site of reactive oxygen species production. Aquatic Toxicology, 2015, 158, 1-13, doi: 10.1016/j.aquatox.2014. 10.014 .

88. MA, Hongbo, BRENNAN, Amanda, DIAMOND, Stephen A. Phototoxicity of $\mathrm{TiO}_{2}$ Nanoparticles under Solar radiation to two aquatic species: Daphnia Magna and Japanese Medaka. Environmental Toxicology and Chemistry, 2012, 31(7), 1621-1629, doi: 10.1002/etc.1858.

89. MILLER, Robert J., BENNETT, Samuel, KELLER, Arturo A., PEASE, Scott, LENIHAN, Hunter S. TiO2 nanoparticles are phototoxic to marine phytoplankton. PLoS ONE, 2012, 7(1), 1-7, doi: 10.1371/journal.pone.0030321.

90. MA, Hongbo, WALLIS, Lindsay K., DIAMOND, Steve, LI, Shibin, CANAS-CARRELL, Jaclyn, PARRA, Amanda. Impact of solar UV radiation on toxicity of $\mathrm{ZnO}$ nanoparticles through photocatalytic reactive oxygen species (ROS) generation and photo-induced dissolution. Environmental Pollution, 2014, 193, 165-172, doi: 10. 1016/j.envpol.2014.06.027.

91. ADAMS, Laura K., LYON, Delina Y., ALVAREZ, Pedro J. J. Comparative eco-toxicity of nanoscale $\mathrm{TiO} 2, \mathrm{SiO} 2$, and $\mathrm{ZnO}$ water suspensions. Water Research, 2006, 40, 3527-3532, doi: 10.1016/j.watres.2006.08.004.

92. MAJED, Seyed Mohammad, KELLY, Barry C., LEE, Hian Kee. Combined effects of water temperature and chemistry on the environmental fate and behavior of nanosized zinc oxide. Science of the Total Environment, 2014, 496, 585-593, doi: 10.1016/j.scitotenv.2014.07. 082.

93. WONG, Stella W. Y., LEUNG, Priscilla T. Y., DJURŠIĆ, A. B., LEUNG, Kenneth M. Y. Toxicities of nano zinc oxide to five marine organisms: influences of aggregate size and ion solubility. Analytical and Bioanalytical Chemistry, 2010, 396, 609-618, doi: 10.1007/s00216-009-3249-z.

94. VON MOSS, Nadia, SLAVEYKOVA, Vera I. Oxidative stress induced by inorganic nanoparticles in bacteria and aquatic microalgae - state of the art and knowledge gaps. Informa, 2014, 8(6), 605-630, doi: 10.3109/17435390.2013.809810.
95. MANIER, Nicolas, BADO-NILLES, Anne, DELALAIN, Patrice, AGUERRE-CHARIOL, Oliver, PANDARD, Pascal. Ecotoxicity of nonaged and aged $\mathrm{CeO} 2$ nanomaterials towards freshwater microalgae. Environmental Pollution, 2013, 180, 63-70, doi: 10.1016/j.envpol. 2013.04.040.

96. VAN HOECKE, Karen, QUIK, Joris T. K., MANKIEWICZ-BOCZEK, Joanna, DE SCHAMPHELARE, Karel A. C., ELSAESSER, Andreas, VAN DER MEEREN, Paul, BARNES, Clifford, MCKERR, George, VYVYAN HOWARD, C., VAN DE MEENT, Dik, RYDZYNSKI, Konrad, DAWSON, Kenneth A., SALVATI, Anna, LESNIAK, Anna, LYNCH, Iseult, SILVERSMIT, Geert, DE SAMBER, Bjorn, VINCZE, Laszlo, JANSSEN, Colin R. Fate and effects of $\mathrm{CeO} 2$ nanoparticles in aquatic ecotoxicity tests. Environmental Science \& Technology, 2009, 43, 4537-4546, doi: 10.1021/ es9002444.

97. BOUR, Agathe, MOUCHET, Florence, VERNEUIL, Laurent, EVARISTE, Lauris, SILVESTRE, Jerome, PINELLI, Eric, GAUTHIER, Laury. Toxicity of $\mathrm{CeO} 2$ nanoparticles at different trophic levels - Effects on diatoms, chironomids and amphibians. Chemosphere, 2015, 120, 230-236, doi: 10.1016/j.chemosphere.2014. 07.012 .

98. VAN KOESTEM, Frederik, VERSTRAETE, Simon, VAN DER MEEREN, Paul, LAING, Gijs Du. Stability of engineered nanomaterials in complex aqueous matrices: Settling behaviour of $\mathrm{CeO} 2$ nanoparticles in natural surface waters. Environmental Research, 2015, 142, 207-214, doi: 10.1016/j.envres.2015.06.028.

99. VON GOETZ, N., LORENZ, C., WINDLER, L., NOWACK, B., HEUBERGER, M., HUNGERBUHLER, K. Migration of Ag- and TiO2(Nano)particles from textiles into artificial sweat under physical stress: experiments and exposure modeling. Environmental Science and Technology, 2013, 47, 9979-9987, doi: 10.1021/ es304329w.

100. SOM, Claudia, WICK, Peter, KRUG, Harald, NOWACK, Bernd. Environmental and health effects of nanomaterials in nanotextiles and façade coatings. Environment International, 2011, 37, 1131-1142, doi: 10.1016/j.envint. 2011.02.013. 
101. SUN, Xiujuan, CHANG, Yun, CHENG, Yan, FENG, Yanlin, ZHANG, Haiyuan. Band alignment-driven oxidative injury to the skin by anatase/rutile mixed-phase titanium dioxide nanoparticles under sunlight exposure. Toxicological Sciences, 2018, 164(1), 300-312, doi: 10.1093/toxsci/kfy088.

102. BRAYNER, Roberta. The toxicological impact of nanoparticles. View Journal Impact, 2008, 3(1-2), 48-55, doi: 10.1016/S1748-0132(08)70015-X.

103. EOM, Hyun-Jeong, CHOI, Jinhee. Oxidative stress of $\mathrm{CeO} 2$ nanoparticles via $\mathrm{p} 38-\mathrm{Nrf}-2$ signaling pathway in human bronchial epithelial cell, Beas-2B. Toxicology Letters, 2009, 187, 77-83, doi: 10.1016/j.toxlet.2009.01.028.

104. KIM, In-Sun, BAEK, Miri, CHOI, Soo-Jin. Comparative cytotoxicity of $\mathrm{Al} 2 \mathrm{O} 3, \mathrm{CeO} 2$, $\mathrm{TiO} 2$ and $\mathrm{ZnO}$ nanoparticles to human lung cells. Journal of Nanoscience and Nanotechnology, 2010, 10(5), 3453-3458, doi: 10.1166/ jnn.2010.2340.

105. SALAT, Marc, PETKOVA, Petya, HOYO, Javier, PERELSHTEIN, Ilana, GEDANKEN, Aharon, TZANOV, Tzanko. Durable antimicrobial cotton textiles coated sonochemically with $\mathrm{ZnO}$ nanoparticles embedded in an in-situ enzymatically generated bioadhesive. Carbohydrate Polymers, 2018, 189, 198-203, doi: 10. 1016/j.carbpol.2018.02.033.

106. DING, Xuecheng, RUI, Qi, WANG, Dayong. Functional disruption in epidermal barrier enhances toxicity and accumulation of graphene oxide. Ecotoxicology and Environmental Safety, 2018, 163, 456-464, doi: 10.1016/j.ecoenv.2018. 07.102 .

107. YANG, Kai, LI, Yingjie, TAN, Xiaofang, PENG, Rui, LIU, Zhuang. Behavior and toxicity of graphene and its functionalized derivatives in biological systems. Small, 2013, 9(910), 1492-1503, doi: 10.1002/smll.201201417.

108. CHATTERJEE, Nivedita, KIM, Youngho, YANG, Jisu, ROCA, P. Carlos, JOO, SangWoo, CHOI, Jinhee. A systems toxicology approach reveals the Wnt-MAPK crosstalk pathway mediated reproductive failure in Caenorhabditis elegans exposed to graphene oxide (GO) but not to reduced graphene oxide (rGO). Nanotoxycology, 2017, 11(1), 7686, doi: 10.1080/17435390.2016.1267273.

109. YANG, Ruilong, REN, Mingxia, RUI, Qi, WANG, Dayong. A mir-231-regulated protection mechanism against the toxicity of graphene oxide in nematode Caenorhabditis elegans. Scientific Reports, 2016, 6, article number: 32214, doi: 10.1038/srep32214.

110. XIAO, Guosheng, CHEN, He, KRASTEVA, Natalia, LIU, Qizhan, WANG, Dayong. Identification of interneurons required for the aversive response of Caenorhabditis elegans to graphene oxide. Journal of Nanobiotechnolo$g y, 2018,16(1)$, doi: 10.1186/s12951-0180373-y.

111. LI, Ping, XU, Tiantian, WU, Siyu, LEI, Lili, HE, Defu. Chronic exposure to graphene-based nanomaterials induces behavioral deficits and neural damage in Caenorhabditis elegans. Journal of Applied Toxicology, 2017, 37(10), 1140-1150, doi: 10.1002/jat.3468.

112. CHEN, He, LI, Huirong, WANG Dayong. Graphene oxide dysregulates neuroligin/nlg-1mediated molecular signaling in interneurons in Caenorhabditis elegans. Scientific Reports, 2017, 7, article number: 41655, doi: 10.1038/srep4165.

113. ZHANG, Xiaoyong, YIN, Jilei, PENG, Cheng, HU, Weiqing, ZHU, Zhiyong, LI, Wenxin, FAN, Chunhai, HUANG, Qing. Distribution and biocompatibility studies of graphene oxide in mice after intravenous administration. Carbon, 2011, 49(3), 986-995, doi: 10.1016/j. carbon.2010.11.005.

114. YANG, Kai, GONG, Hua, SHI, Xiaoze, WAN, Jianmei, ZHANG, Youijiu, LIU, Zhuang. In vivo biodistribution and toxicology of functionalized nano-graphene oxide in mice after oral and intraperitoneal administration. View Journal Impact, 2013, 34(11), 2782-2795, doi: 10.1016/j.biomaterials.2013.01.001. 